\title{
Supervision of Financial Reporting Through the Prism of the Regulatory Framework and Practice in the Republic of Serbia
}

\author{
Article history: \\ Received: 30 August 2016 \\ Sent for revision:28 September 2016 \\ Received in revised form: 29 December 2016 \\ Accepted: 30 December 2016 \\ Available online: 5 April 2017
}

\begin{abstract}
The paper presents the research in the field of internal supervision in financial reporting in the private sector of the Republic of Serbia. In the first part of the paper, legal regulations and current international regulations are compared. The aim of this study was to evaluate the achieved level of harmonization between the national and international regulatory framework in the field of financial reporting. The second part of the paper presents the analysis of the effect of the internal supervision in financial reporting on comparability of financial statements in terms of consistent application of the regulatory framework. The study aimed at examining whether internal supervision affects the comparability of financial statements. The methodology of the research that was used in the processing of data obtained through the questionnaire consisted of One-Factor Analysis of Variance, Pearson's correlation coefficient, and Spearman's and Kendall's rank correlation coefficient. The sample included 297 employees working on accounting and/or audit positions of the private sector of the Republic of Serbia. The results showed a (partial) non-compliance of domicile regulations with EU regulations, i.e. that the national regulatory framework is not harmonized with international regulatory framework. In addition, the results indicated that the internal supervision, defined both in domicile and EU regulations, contributes to the comparability of financial statements in terms of consistent application of the regulatory framework.
\end{abstract}

Keywords: internal supervision, financial reporting, regulatory framework, harmonization, comparability, regulation.

\footnotetext{
${ }^{1}$ University of Novi Sad, The Faculty of Economics in Subotica, suncica@ef.uns.ac.rs

${ }^{2}$ University of Novi Sad, The Faculty of Economics in Subotica
} 
Milutinović S., Medved I.: Supervision of Financial Reporting Through the Prism of...

\title{
Nadzor u finansijskom izveštavanju kroz prizmu regulatornog okvira i prakse u R. Srbiji
}

\begin{abstract}
Apstrakt: $U$ radu je izvršeno istraživanje iz oblasti internog nadzora $u$ finansijskom izveštavanju u privatnom sektoru $R$. Srbije. U prvom delu rada izvršena je komparacija zakonske sa aktuelnom međunarodnom regulativom. Cilj istraživanja je bio da se proceni dostignut nivo harmonizacije nacionalnog sa međunarodnim regulatornim okvirom u oblasti finansijskog izveštavanja. U drugom delu rada istražen je uticaj internog nadzora u finansijskom izveštavanju na uporedivost finansijskih izveštaja u uslovima dosledne primene regulatornog okvira. Cilj istraživanja je bio da se ispita da li interni nadzor utiče na uporedivost finansijskih izveštaja. Metodologija istraživanja koja je korišćena pri obradi podataka dobijenih putem upitnika obuhvatala je jednofaktorsku analizu varijanse, Pirsonov koeficijent linearne korelacije, te Spirmanov i Kendalov koeficijent korelacije ranga. Uzorak je obuhvatao 297 zaposlenih na pozicijama računovodstva i/ili revizije u privatnom sektoru $R$. Srbije. Rezultati su pokazali da postoji (delimična) neusklađenost domicilne regulative sa regulativom EU, odnosno da nacionalni regulatorni okvir nije harmonizovan sa međunarodnim regulatornim okvirom. Takođe, rezultati su pokazali da interni nadzor, definisan kako u domicilnoj, tako i u regulativi EU, doprinosi uporedivosti finansijskih izveštaja u uslovima dosledne primene regulatornog okvira.
\end{abstract}

Ključne reči: nadzor, finansijsko izveštavanje, regulatorni okvir, harmonizacija, uporedivost, regulativa.

\section{Introduction}

The influence of the internal supervision of financial reporting on different categories (variables) is not rarely studied outside Serbia, but the same or similar research has not been conducted so far in domestic practice. On the other hand, foreign authors are frequently engaged in the research in this field. Doyle, Ge and McVay (2007) have examined determinants of weaknesses in internal control for 779 firms disclosing material weaknesses. Dobija (2015) has investigated audit committee practices in relation to the oversight of financial reporting and external auditors in Polish public interest entities. Abbott, Daugherty, Parker and Peters (2016) have examined an interactive model of internal audit functions quality (comprised of competence and independence) to better understand the determinants of internal audit functions effectiveness as a financial reporting monitor. Ge, Li, Liu and McVay (2016), exploiting a rich Chinese dataset, have examined whether internal control over financial reporting reduces the expropriation of resources from 
Milutinović S., Medved I.: Supervision of Financial Reporting Through the Prism of...

the firm by managers and controlling shareholders. Altamuro and Beatty (2010) have examined the internal control provisions mandated by the Federal Depository Insurance Corporation Improvement Act during the early 1990 s to investigate how internal control regulation affects financial reporting study examines both the validity of specific accounts and the quality of financial reporting.

Feng, Li, McVay and Skaife (2015) have investigated whether ineffective internal control over financial reporting has implications for firm operations by examining the association between inventory-related material weaknesses in internal control over financial reporting and firms' inventory management. Bardhan, Lin and Wu (2015) have studied the relationship between family firm characteristics and the quality of internal control over financial reporting, relative to non-family firms using a relatively large sample of S\&P 500 firms. Azzali and Mazza (2013), selecting a sample of listed companies in the manufacturing, service and finance industries in Italy, have investigated the relation between the internal control over financial reporting quality and information technology control frameworks compliance. Marinovic (2013) proposes a new measure of earnings quality based on the probability that the firm's internal control system is effective that has strong theoretical foundations and can be estimated using either the time series of earnings or the relation between earnings and prices. Guided by the organizational theory which suggests that firms following an innovative "prospector" strategy are likely to have weaker internal controls than firms following an efficient "defender" strategy, Bentley-Goode, Newton and Thompson (2015) have examined whether a firm's business strategy is an underlying determinant of the quality of its internal control over financial reporting.

Interpretation of supervision is best described by Isaac (1951, 7-9), who after making an etymologically sharp demarcation between the terms of audit, supervision, control and inspection, concluded that they have to complement each other in order to achieve adequate supervision of the business entity. Therefore, Isaac incorporates audit, control and inspection under the concept of "supervision". In this paper, supervision will be observed under this comprehensive term.

The specific aim of the research in financial reporting could be put in the form of a question: Why research is done in financial reporting? The research aims to supplement the theoretical assumptions with the results of the empirical research in the area where they are very rare (at least in domestic practice). The research also enables feedback from practice to the creators of the regulatory framework through the obtained research results.

The aims of this study were to evaluate the achieved level of harmonization between the national and international regulatory framework in the field of financial reporting, and to exam whether internal supervision affects the 
Milutinović S., Medved I.: Supervision of Financial Reporting Through the Prism of...

comparability of financial statements. The hypothesis that is the subject of the research in this paper reads: Supervision of financial reporting contributes to the comparability of financial statements in terms of consistent application of the regulatory framework.

The research results are important because the creators of the national regulatory framework, which legally shape the financial reporting, can be thus informed about the "facts on the ground". Timely feedback from practice is a key determinant of a well-designed regulatory and internal regulation, and therefore this study is important not only for the creators of the regulatory framework, but for the members of the accountancy profession, supervisory bodies and management bodies in a business entity.

Originality is reflected in the fact that similar studies have not yet been implemented in domestic practice. The importance of the research is undeniable, given the fact that the area of financial reporting is very dynamic in terms of frequent changes of regulations, both professional and legal. In order to timely observe novelties and effects of changes in this area, constant research is necessary, especially in the domestic practice as it unjustifiably lacks this type of research.

\section{Review of the Regulatory Framework of Financial Reporting}

\subsection{Government Bodies as the Creators of the National Regulatory Framework}

The government and its regulatory and control bodies create laws and regulations in the field of management, supervision and quality control of financial reporting at the national level. In Serbia, the most important law regulating this area is the Law on Accounting (Official Gazette of RS, 2013). The government's supervisory and regulatory bodies in the field of accounting are: Department for Financial System of the Ministry of Finance, The National Commission for Accounting, State Audit Institution and Tax Administration.

The Ministry of Finance of the Republic of Serbia within its jurisdiction performs state administration tasks from the scope of operations of the national budget, public finance, international financial relations, banking system and accounting and auditing system. The final area is the responsibility of the Department for Financial System - Group for Accounting and Auditing. "Group for Accounting and Auditing performs normative work on the preparation of laws and related regulations in the field of accounting and auditing, monitors the implementation of legislation on accounting and 
Milutinović S., Medved I.: Supervision of Financial Reporting Through the Prism of...

auditing, and works on its harmonization with the directives and standards, provides support and participates in the work of the National Commission for Accounting, carries out activities related to the monitoring of legislative activity in the field of International Accounting Standards, i.e. International Financial Reporting Standards (IAS/IFRS) and International Financial Reporting Standards for Small and Medium-Sized Entities (IFRS for MSEs), as well as supports and participates in the work of the Commission to confirm interpretation of IAS/IFRS and IFRS for MSEs, monitors the implementation of EU directives, International Standards on Auditing (ISA) and related international standards (...)" (Ministry of Finance RS, 2014, 35).

The National Commission for Accounting (hereinafter NCA) established by the Law on Accounting and Auditing from 2006, continues to operate under the provisions of the new law, but within the scope of its duties and responsibilities it performs only two out of five tasks that were assigned by the previous law. NCA now has the following two tasks (Official Gazette of RS, 2013, Article 42): to monitor the implementation of European Union directives in the field of accounting and propose appropriate solutions for national legislation; to monitor the application of IFRS and IFRS for MSEs and provide opinion to the Ministry on the interpretation of these standards, as well as solutions for any problems that may arise in the process of applying these standards. In addition to two mentioned tasks, under the previous Law on Accounting and Auditing the NCA had the following tasks: to monitor changes in international accounting and auditing regulation and report to the Ministry, then to propose a strategy, guidelines and an action plan to improve the quality of financial reporting and initiate the adoption of new or changes to existing regulations in the field of accounting, as well as to cooperate with the Ministry, the Chamber of Certified Auditors, universities, as well as with national professional organizations (Stojanović \& Petrović, 2013, 17).

State Audit Institution (hereinafter SAI) is the highest audit authority of public funds in the Republic of Serbia. It is established in 2005 under the Law on State Audit Institution. SAI is an independent state authority and its operation is supervised by the National Assembly. SAI conducts external audit of the public sector and is a key link in the system of financial accountability in the Republic of Serbia. The primary function of the audit is to provide independent reporting on programs, functions, activities and operations of entities that use public funds, to provide reliable inspection and evaluation of the functioning of the public sector in order to enable the accountability mechanism of the government. It assures that state revenues are allocated appropriately and that public funds and assets are managed in a financially stable way and in accordance with the decisions and intentions of the National Assembly of the Republic of Serbia. Through its work, this institution aims to contribute to reducing corruption and increasing the anti-corruption culture in society. The mission of SAI, as the highest body of state and independent audit authority of 
Milutinović S., Medved I.: Supervision of Financial Reporting Through the Prism of...

public funds, is to provide professional assurance to the National Assembly of the Republic of Serbia and its citizens that public funds are used effectively, efficiently and economically. SAl's vision is to become a recognizable, reliable and independent institution that aims to contribute to parliamentary scrutiny and good governance in the public sector.

Tax Administration indirectly supervises the implementation of the Accounting Law through the control of business entities for activities in the field of accounting by checking accounting records, business records, financial statements, and operating system for accounting (Mitrović, 2013, 73-75). Applying its positions in the control of taxation and carrying out tasks within the scope of the legal framework, the Tax Administration shall verify the accuracy of recording transactions in the ledgers of the taxpayers, from the aspect of mathematical accuracy, formal correctness and completeness of the financial statements submitted to the Tax Administration. In addition, within its scope of authority, "Tax Administration checks the accuracy, completeness and compliance with the law or other regulations of the data stated in the tax return and tax balance, accounting reports and other records of the taxpayer, by comparison with data from tax accounting and other official records kept by or available to the Tax administration." (Official Gazette RS, 2016, Articles 119 and 120). Tax administration has the right to interpret and determine the way of accounting coverage of certain business events, although it is not directly related to its scope of authority, with the aim of showing the exact financial and material flows, combating the grey economy and illegal flows of goods and money.

\subsection{Harmonisation of the National Regulatory Framework of Financial Reporting}

The harmonization of the national and international regulatory framework in the field of accounting is particularly important for countries in transition where the inflow of foreign capital is extremely important. When it comes to domestic practice, it is necessary to point out two important facts, namely that the international accounting regulation is the factor in the quality of financial reporting, on the one hand, but also the instrument of harmonization of financial reporting, on the other hand. Besides international accounting regulations, other key factors that determine the quality of financial reporting in the Republic of Serbia are the following (Mitrović, 2013, 63): the state, the education system, regulatory bodies, professional organizations and independent bodies whose task is to control the quality of financial reporting.

Unfortunately, still prevailing opinion in the domestic practice is that international accounting regulation is a mere obligation, another novelty, the change which should be complied with, and thereby two important facts above 
Milutinović S., Medved I.: Supervision of Financial Reporting Through the Prism of...

are ignored. However, Serbia is not an exception regarding the (partial) noncompliance of domicile regulations with EU regulations. In most developing countries, the regulations on accounting and auditing are not fully compliant with the relevant elements of fundamental Acquis on financial reporting and auditing" (Šabović, 2011, 96). Regulations on accounting and auditing are not harmonized with the Acquis mainly in the preparation of management reports, preparation of semi-annual reports for listed companies, electronic publication of financial statements, approval and registration of audit firms and the preparation of consolidated accounts.

The most significant features of accounting regulations in Serbia are:

- The legislation has priority over the professional accounting regulation, which is contrary to the practice of economically highly-developed countries.

- Applied accounting regulation depends primarily on the size of the business entity, which is in accordance with the practice of EU Member States.

- A special law regulates accounting, while other special law regulates auditing, which is the first such case in Europe. Serbia lacks a strong legal basis in the form of the Commercial Code as the most famous codification of commercial law, which is the case with most countries in the EU. One gets the impression that not much is done on commercial law since 1991, although socialism was abandoned more than two decades ago, which led to changes in social, political and economic life in the region.

- There are no national accounting standards, as is the case in $25 \mathrm{EU}$ countries. Unless they are required to use IFRS, business entities in Serbia opt for IFRS for MSEs or insufficiently clear Rules prescribed by the competent ministry.

- The legislation does not comply with Directive 2013/34/EU. Although the Accounting Law was adopted in July 2013, its alignment was done with IV and VII Directive, which already ceased to exist back then (for more details see 1.3).

Given the characteristics listed above, accounting regulations in Serbia do not inspire trust that their implementation can achieve high-quality financial reporting and comparability at the international level, let alone achieve the basic goal of financial reporting (IASB, 2010): providing financial information about the reporting entity that is useful to existing and potential investors, lenders and other creditors in making decisions about providing resources to the entity. According to Šabović $(2011,97)$, specific actions to be implemented in developing countries in order to harmonize financial reporting relate to the following three activities: (1) extension of statutory and 
Milutinović S., Medved I.: Supervision of Financial Reporting Through the Prism of...

institutional framework; (2) development of supervision mechanism; (3) effects of market discipline.

Extension of statutory framework includes statutory completion of implementation of all segments of the international professional accounting regulations and principles of accounting and auditing profession. Extension of institutional framework includes the strengthening of all domestic institutions under the jurisdiction of the state that contribute to the achievement of the objectives (Ministry of Finance, National Bank of Serbia, the Agency for Business Registers, Tax Administration, the Securities Commission and other institutions). Supervision mechanism includes a system based on strengthening the following key pillars of control: internal audit, top management, audit committees and the accounting profession. The market discipline treats all those elements that contribute to an active relationship of the market towards the financial reporting, such as access, comparability, active participation and a positive rebound impact on the basis of information from financial statements.

\section{Chart 1: Conditions of quality completion of the process of harmonization of} the financial reporting system of the Republic of Serbia

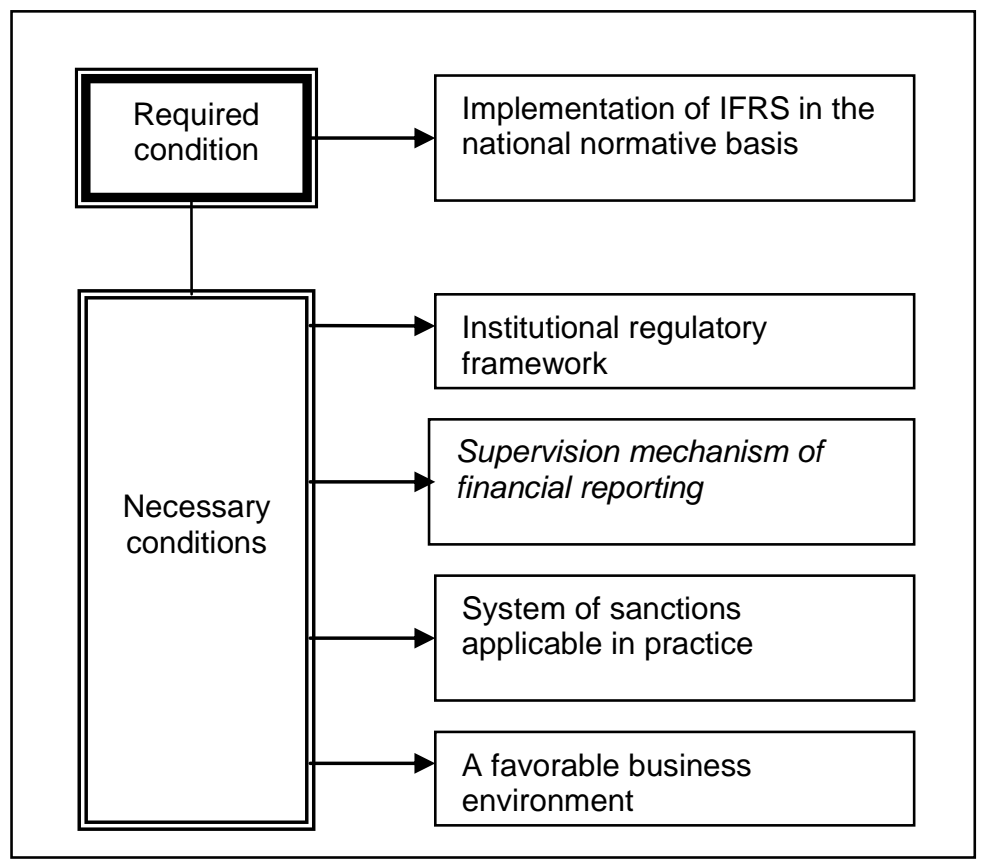

Source: the authors 
Milutinović S., Medved I.: Supervision of Financial Reporting Through the Prism of...

Implementation of the International Financial Reporting Standards (IFRS) into national legislation is a necessary but not sufficient requirement in the process of harmonization of financial reporting (see Chart 1). It would be necessary in the coming period to work on the segment of supervision of financial reporting, which has so far been unjustifiably neglected.

The path chosen by Serbia two decades ago towards the harmonization of financial reporting was well founded, but in the last ten years the good course is disrupted. Getting back on track can be achieved with further improvements (especially in the national regulatory framework), greater cooperation between state bodies and professional organizations (the latter showing interest) and education of participants in the creation and implementation of accounting regulations on the importance and benefits of the harmonization of financial reporting, which will result in faster and easier overcoming of numerous obstacles (Klikovac, 2009, 46-53) that the process of harmonization inevitably entails.

\subsection{Incorporation of EU Directives into the National Regulatory Framework}

EU directives are part of the so-called Acquis Communautaire, which represents entire legislation applicable in the EU. To join the EU, a country must meet certain conditions, and one of them is the acceptance, adoption and implementation of the entire Acquis Communautaire. In particular, the directives are part of the secondary legislation of Acquis Communautaire and their specificity is reflected in the fact that through their application national regulations harmonize, i.e. level, but not completely equalize. In other words, a certain degree of freedom is left to national legislators for planning of the national regulations. Directives are not binding, but it is recommended to include their wording in the national legislation.

Shortly after the adoption of Directive 2013/34/EU, a new Law on Accounting of the Republic of Serbia was enacted. Whether and to what extent the legislator took into account the compliance of this Law with the newly adopted Directive is shown in Table 1 with comparative overview of the most important parts of both segments of the regulation.

It can be concluded that the legislator at the stage of preparation and adoption of the Law did not take into consideration the novelties introduced by the Directive 2013/34/EU. The scope of the Law is broader than the scope of the Directive, because the Directive covers only profit legal entities in the form of a company. 
Milutinović S., Medved I.: Supervision of Financial Reporting Through the Prism of...

Table 1: Comparative overview of the most important parts of Directive 2013/34/EU and Accounting Law of 2013

\begin{tabular}{|c|c|c|}
\hline $\begin{array}{l}\text { The most important } \\
\text { segments }\end{array}$ & Directive 2013/34/EU & Accounting Law \\
\hline $\begin{array}{l}\text { Public media and the } \\
\text { publication date }\end{array}$ & $\begin{array}{l}\text { The Official Journal of the } \\
\text { European Union }\left(29^{\text {th }} \text { June }\right. \\
\text { 2013) }\end{array}$ & $\begin{array}{l}\text { Official Gazette of RS, } 62 / 2013 \\
\left(17^{\text {th }} \text { July } 2013\right)\end{array}$ \\
\hline Effective Date & $19^{\text {th }}$ July 2013 & $25^{\text {th }}$ July 2013 \\
\hline Scope & $\begin{array}{l}\text { Joint stock companies, limited } \\
\text { liability companies, limited } \\
\text { partnerships, general } \\
\text { partnerships (non-profit legal } \\
\text { entities are excluded from the } \\
\text { scope of the Directive) }\end{array}$ & $\begin{array}{l}\text { Legal entities (companies, NBS, } \\
\text { banks, financial institutions, etc.), } \\
\text { Other legal entities and } \\
\text { entrepreneurs (non-profit legal } \\
\text { entities are included in the scope } \\
\text { of the Law) }\end{array}$ \\
\hline $\begin{array}{l}\text { Responsibility for the } \\
\text { development and } \\
\text { publication of } \\
\text { financial statements }\end{array}$ & $\begin{array}{l}\text { Members of the administration } \\
\text { (e.g. Accounting department, } \\
\text { accounting division or } \\
\text { function, etc.), management } \\
\text { and supervisory body of the } \\
\text { legal entity have a collective } \\
\text { responsibility }\end{array}$ & $\begin{array}{l}\text { Legal representative, managing } \\
\text { authority, the supervisory body of } \\
\text { the legal entity and the person } \\
\text { responsible for bookkeeping and } \\
\text { preparing financial statements }\end{array}$ \\
\hline $\begin{array}{l}\text { Consolidated } \\
\text { Financial Statements }\end{array}$ & $\begin{array}{l}\text { Parent companies listed in } \\
\text { Annex I (and in certain } \\
\text { circumstances, in Annex II) } \\
\text { are obliged to make them }\end{array}$ & $\begin{array}{l}\text { All parent legal entities are } \\
\text { obliged to create, present, submit } \\
\text { and disclose them }\end{array}$ \\
\hline $\begin{array}{l}\text { Classification } \\
\text { thresholds for groups } \\
\text { of legal entities }\end{array}$ & $\begin{array}{l}\text { Small groups of legal entities } \\
\text { Medium-sized group of legal } \\
\text { entities } \\
\text { Large groups of legal entities }\end{array}$ & $\begin{array}{l}\text { Do not exist. There are only } \\
\text { criteria for classification of legal } \\
\text { entities }\end{array}$ \\
\hline $\begin{array}{l}\text { Elements of Financial } \\
\text { Reporting }\end{array}$ & $\begin{array}{l}\text { The annual financial } \\
\text { statements, management } \\
\text { report (Report of the } \\
\text { Management Board) and the } \\
\text { report on corporate } \\
\text { governance }\end{array}$ & $\begin{array}{l}\text { Regular annual financial } \\
\text { statements and annual report on } \\
\text { operations (only for large legal } \\
\text { entities and public companies) }\end{array}$ \\
\hline $\begin{array}{l}\text { Regular (basic) } \\
\text { financial statements }\end{array}$ & $\begin{array}{l}\text { Balance sheet, income } \\
\text { statement and notes to the } \\
\text { financial statements }\end{array}$ & $\begin{array}{l}\text { Balance sheet, income statement, } \\
\text { statement of other comprehensive } \\
\text { income, statement of changes in } \\
\text { equity, cash flow statement and } \\
\text { notes }\end{array}$ \\
\hline $\begin{array}{l}\text { Obligation to audit } \\
\text { financial statements }\end{array}$ & $\begin{array}{l}\text { Large, medium-sized and } \\
\text { legal entities of public interest } \\
\text { (exemption of small and micro } \\
\text { legal entities) }\end{array}$ & $\begin{array}{l}\text { Large, medium-sized companies, } \\
\text { public companies and all legal } \\
\text { entities with business income } \\
\text { exceeding } € 4.4 \text { million }\end{array}$ \\
\hline
\end{tabular}

Source: the authors

The directive defines collective responsibility in financial reporting shared by approximately the same bodies in a legal entity as per the law, with the added responsibility of the legal representative under the law. The differences 
Milutinović S., Medved I.: Supervision of Financial Reporting Through the Prism of...

appear in the following segments: the obligation of drawing up consolidated financial statements (wider scope under the law, because it covers all parent legal entities), classification thresholds for groups of legal entities (not recognized by the law), elements of financial reporting in part of additional financial statements as well as the structure of regular financial statements. Obligation to audit financial statements is similarly defined, except that in the Directive, regardless of the public interest, small and micro legal entities are excluded, while the law implies audit for all legal entities with a certain level of operating income on an annual basis. Research in domestic practice was already conducted on fulfilling the legal obligations for the audit of the Report of cash flows in terms of the size of legal entities (Miletić, 2014, 106).

The paper will be focused on the responsibility over the process of financial reporting, as this area is, inter alia, the jurisdiction of the supervisory bodies of a legal entity, both according to Directive 2013/34/EU and the Accounting Law.

\section{Research Methodology}

\subsection{Research and Sample}

The research sample covered all employees in the accounting and/or auditing positions in the private sector of the Republic of Serbia, regardless of their professional title and years of experience. The sample meets all the requirements of a representative sample and consists of 297 respondents. A random sample in the research is considered an ideal sample. The sample in this study was selected randomly, because every member of the basic set had the same chances, i.e. the same probability of being selected into the sample. In addition, the selection of each member of the sample was independent, i.e. the selection of one member did not influence the selection of any other member of the sample.

The study was conducted during 2014-2015, and this period was chosen for two reasons. End of the third quarter of 2014 was the earliest possible time for the start of the research, given the recent amendments in the legal framework of accounting in the Republic of Serbia. IFRS for MSEs and several regulations in the field of accounting were adopted in late 2013, which, among other things, specified new financial statement forms and new Chart of Accounts. However, before their implementation, new financial statement forms and the new Chart of Accounts were defined again, which entered into force on $13^{\text {th }}$ September 2014. Chart of Accounts was amended for the third time in a year at the end of December 2014. 
Milutinović S., Medved I.: Supervision of Financial Reporting Through the Prism of...

End of the first half of 2015 was the earliest possible period for the completion of the research, because IFRS for MSEs was applied for the first time for financial statements, which were prepared on $31^{\text {st }}$ December 2014 and the deadline for their submission was $31^{\text {st }}$ March 2015. This was also the first time financial statements were prepared using the latest forms and the amended structure and scope.

Finally, the research faced the same problems that usually appear in research of financial reporting:

- Research cannot be conducted in conditions of a controlled experiment.

- It is impossible to include all variables and identify all the factors that influence the research problem.

- The research sample is often small.

- Any research, including one in the area of financial research, comprises mistakes, both those that can be predicted before the start of the research and mistakes that cannot be predicted.

However, these problems have not significantly affected the independence and regularity of the research, nor the credibility and presentation capacity of the obtained results.

\subsection{Hypotheses and Methodology}

The null hypothesis $(\mathrm{H} 0)$ that is the subject of the research in this paper reads: Supervision of financial reporting contributes to the comparability of financial statements in terms of consistent application of the regulatory framework. The null hypothesis will be proved using the following auxiliary hypotheses h:

- H01: Supervision over the process of preparation and presentation of financial statements by internal authorities contributes to the comparability of financial statements at the level of Serbia.

- H02: Supervision over compliance of financial statements with the regulatory framework by the internal authorities contributes to the comparability of financial statements at the level of Serbia.

- H03: There is a positive correlation between the supervision over the process of preparation and presentation of financial statements by internal authorities and comparability of financial statements at the level of Serbia.

- H04: There is a positive correlation between the supervision over compliance of financial statements with a regulatory framework by the internal authorities and the comparability of financial statements at the level of Serbia. 
Milutinović S., Medved I.: Supervision of Financial Reporting Through the Prism of...

Null hypothesis $(\mathrm{HO})$ and auxiliary hypotheses $(\mathrm{H} 01, \mathrm{H} 02, \mathrm{H} 03, \mathrm{H} 04)$ are tested based on the interdependent variables c. 1 and c.2 and the dependent variable x.1:

- c.1 - in the last three years, the internal authorities exercised supervision over the process of preparation and presentation of financial statements,

- c.2 - in the last three years, the internal authorities exercised supervision over compliance of financial statements with the regulatory framework,

- x.1 - financial statements of the legal entity that employs you are comparable with financial statements of other legal entities in Serbia prepared on the basis of the regulatory framework.

To test the null hypothesis in order to prove it, one-way analysis of variance (one-way ANOVA) will be used. After ANOVA, the degree of correlation between the observed variables below will be studied using the Pearson's correlation coefficient (Pearson's r), i.e. its non-parametric alternatives Spearman's rank correlation coefficient (Spearman's rho) and Kendall's rank correlation coefficient (Kendall's tau_b). The assumption of independence of observations is used among other necessary conditions for the use of the correlation as the statistical technique. Given the spatial and temporal dynamics and manner of sending the questionnaire, then territorial heterogeneity of respondents, it was possible to avoid data collection in a group setting, as well as any form of interaction between respondents.

\section{Results and Discussion}

\subsection{Supervision over the Process of Preparation and Presentation of Financial Statements}

The parametric technique of ANOVA displayed the effect of the independent variable $c .1$ - in the last three years, the internal authorities exercised supervision over the process of preparation and presentation of financial statements, on comparability of the financial statements at the level of Serbia (see Table 2). With probability of $95 \%$, a statistically significant difference was determined between the mean values of the dependent variable c. 1 at the level $p<0.05$ between four groups of respondents in the sample in terms of comparability of financial statements at the level of Serbia. Accordingly, subsequent tests were done to determine which group is different from which other groups. 
Milutinović S., Medved I.: Supervision of Financial Reporting Through the Prism of...

Table 2: ANOVA for the independent variable c.1

Dependent variable: Comparability of FS with FS of legal entities in Serbia

\begin{tabular}{|l|r|r|r|r|r|}
\hline & Sum of Squares & $d f$ & Mean Square & $F$ & Sig. \\
\hline Between Groups & 2.571 & 3 & .857 & 3.280 & .021 \\
Within Groups & 76.547 & 293 & .261 & & \\
Total & 79.118 & 296 & & & \\
\hline
\end{tabular}

Source: authors' calculation

Subsequent comparisons using Tukey's HSD test (see Table 3) show a statistically significant difference between the mean values of the first and third group of respondents, as well as between the second and the first group of respondents. In other words, there is a statistically significant difference between the respondents whose companies are never supervised and those where supervision is frequently performed by the internal bodies over the process of preparation and presentation of financial statements, and in terms of comparability of financial statements at the level of Serbia. In addition, there is a statistically significant difference between respondents whose companies are sometimes supervised and those where supervision is never performed by the internal bodies over the process of preparation and presentation of financial statements, and in terms of comparability of financial statements at the level of Serbia. In other words, the opinion of the respondents about the level of comparability of financial statements at the level of Serbia, differs significantly between the first and third, i.e. the second and first group of respondents.

Table 3: Multiple comparisons for c. 1 as per Tukey HSD test

Dependent variable: Comparability of FS with FS of legal entities in Serbia

\begin{tabular}{|c|c|c|c|c|c|c|}
\hline \multirow{2}{*}{$\begin{array}{l}\text { (I) Supervision over } \\
\text { the process of } \\
\text { preparation and } \\
\text { presentation of FS by } \\
\text { internal bodies }\end{array}$} & \multirow{2}{*}{$\begin{array}{l}\text { (J) Supervision over } \\
\text { the process of } \\
\text { preparation and } \\
\text { presentation of FS by } \\
\text { internal bodies }\end{array}$} & \multirow{2}{*}{$\begin{array}{c}\text { Mean } \\
\text { Differenc } \\
e(I-J)\end{array}$} & \multirow{2}{*}{$\begin{array}{l}\text { Std. } \\
\text { Error }\end{array}$} & \multirow[t]{2}{*}{ Sig. } & \multicolumn{2}{|c|}{$\begin{array}{c}95 \% \text { Confidence } \\
\text { Interval }\end{array}$} \\
\hline & & & & & $\begin{array}{l}\text { Lower } \\
\text { Bound }\end{array}$ & $\begin{array}{l}\text { Upper } \\
\text { Bound }\end{array}$ \\
\hline \multirow{3}{*}{ 1. Never } & 2. Sometimes & $\begin{array}{l}-.041 \\
\end{array}$ & .079 & .955 & -.25 & .16 \\
\hline & 3. Frequently & $-.247^{*}$ & .086 & .021 & -.47 & -.03 \\
\hline & 4. Always & -.143 & .081 & .298 & -.35 & .07 \\
\hline \multirow{3}{*}{ 2. Sometimes } & 1. Never & .041 & .079 & .955 & -.16 & .25 \\
\hline & 3. Frequently & $\begin{array}{l}-.206 \\
-10 ?\end{array}$ & .088 & .091 & $\begin{array}{r}-.43 \\
-32\end{array}$ & .02 \\
\hline & $\begin{array}{l}\text { 4. Always } \\
\text { 1. Never }\end{array}$ & $\begin{array}{l}-.102 \\
.247^{*}\end{array}$ & .084 & $\begin{array}{l}.621 \\
021\end{array}$ & $\begin{array}{r}-.32 \\
03\end{array}$ & $\begin{array}{r}.12 \\
47\end{array}$ \\
\hline \multirow[t]{3}{*}{ 3. Frequently } & 2. Sometimes & .206 & .088 & .091 & -.02 & .43 \\
\hline & 4. Always & 105 & .090 & .654 & -.13 & .34 \\
\hline & 1. Never & .143 & .081 & .298 & -.07 & .35 \\
\hline \multirow[t]{2}{*}{ 4. Always } & 2. Sometimes & .102 & .084 & .621 & -.12 & .32 \\
\hline & 3. Frequently & -.105 & .090 & .654 & -.34 & .13 \\
\hline
\end{tabular}

Source: authors' calculation 
Milutinović S., Medved I.: Supervision of Financial Reporting Through the Prism of...

Despite the statistical significance, the actual difference between the mean values of the groups is of small significance. The size of this difference expressed using squared association degree indicator (i.e. Eta square) is 0.032 for $F(3.293)=3.3$. This means that in relation to the size of the effect, $3.2 \%$ of the variability in the measurements of the dependent variable can be explained by belonging to a group.

Based on this analysed results of the variable c.1, it can be concluded that supervision over the process of preparation and presentation of financial statements by internal bodies contributes to the evaluation of comparability of financial statements at the level of Serbia. Therefore, the above results indicate that the null hypothesis $\mathrm{HO}$ is confirmed, in part of auxiliary hypothesis H01: supervision over the process of preparation and presentation of financial statements by internal bodies contributes to the comparability of financial statements at the level of Serbia.

\subsection{Supervision over Compliance of Financial Statements with the Regulatory Framework}

The parametric technique of ANOVA studied the effect of independent variable c.2 - in the last three years, the internal authorities exercised supervision over compliance of financial statements with the regulatory framework on comparability of financial statements at the level of Serbia (see Table 4). With probability of $95 \%$, a statistically significant difference was determined between the mean values of the dependent variable c.2 at the level $p<0.05$ between four groups of respondents in the sample in terms of comparability of financial statements at the level of Serbia. Accordingly, subsequent tests were done to determine which group is different from which other groups.

Table 4: ANOVA for the independent variable c.2

Dependent variable: Comparability of FS with FS of legal entities in Serbia

\begin{tabular}{|l|r|r|r|r|r|}
\hline & $\begin{array}{c}\text { Sum of } \\
\text { Squares }\end{array}$ & \multicolumn{1}{|c|}{$\begin{array}{c}\text { Mean } \\
\text { Square }\end{array}$} & \multicolumn{1}{|c|}{ Sig. } \\
\hline Between Groups & 2.755 & 3 & .918 & 3.524 & .015 \\
Within Groups & 76.363 & 293 & .261 & & \\
Total & 79.118 & 296 & & & \\
\hline
\end{tabular}

Source: authors' calculation

Subsequent comparisons using Tukey's HSD test (see Table 5) show a statistically significant difference between the mean values of the first and third group of respondents, as well as between the third and the first group of respondents. In other words, there is a statistically significant difference between the respondents whose companies are never supervised and those 
Milutinović S., Medved I.: Supervision of Financial Reporting Through the Prism of...

where supervision is always performed by the internal bodies over the process of preparation and presentation of financial statements, and in terms of comparability of financial statements at the level of Serbia. In addition, there is a statistically significant difference between respondents whose companies are frequently supervised and those where supervision is never performed by the internal bodies over the process of preparation and presentation of financial statements, and in terms of comparability of financial statements at the level of Serbia. In other words, the opinion of the respondents about the level of comparability of financial statements at the level of Serbia, differs significantly between the first and fourth, i.e. the third and first group of respondents.

Table 5: Multiple comparisons for c.2 as per Tukey HSD test

Dependent variable: Comparability of FS with FS of legal entities in Serbia

\begin{tabular}{|c|c|c|c|c|c|c|}
\hline \multirow{2}{*}{$\begin{array}{l}\text { (I) Supervision over } \\
\text { compliance of FS with } \\
\text { the regulatory } \\
\text { framework by the } \\
\text { internal bodies }\end{array}$} & \multirow{2}{*}{$\begin{array}{l}\text { (J) Supervision over } \\
\text { compliance of FS with } \\
\text { the regulatory } \\
\text { framework by the } \\
\text { internal bodies }\end{array}$} & \multirow{2}{*}{$\begin{array}{c}\text { Mean } \\
\text { Difference } \\
(I-J)\end{array}$} & \multirow{2}{*}{$\begin{array}{l}\text { Std. } \\
\text { Error }\end{array}$} & \multirow[t]{2}{*}{ Sig. } & \multicolumn{2}{|c|}{$\begin{array}{c}95 \% \text { Confidence } \\
\text { Interval }\end{array}$} \\
\hline & & & & & $\begin{array}{l}\text { Lower } \\
\text { Bound }\end{array}$ & $\begin{array}{l}\text { Upper } \\
\text { Bound }\end{array}$ \\
\hline \multirow{3}{*}{ 1. Never } & 2. Sometimes & -.181 & .080 & .111 & -.39 & .03 \\
\hline & 3. Frequently & -.185 & .082 & .108 & -.40 & .03 \\
\hline & 4. Alwe & $-.225^{*}$ & .081 & .029 & -.43 & -.02 \\
\hline \multirow{3}{*}{ 2. Sometimes } & 1. $\mathrm{NeV}$ & .181 & .080 & .111 & -.03 & .39 \\
\hline & 3. Frequently & -.004 & .091 & 1.000 & -.24 & .23 \\
\hline & 4. Always & -.044 & .091 & .963 & -.28 & .19 \\
\hline \multirow{4}{*}{ 3. Frequently } & 1. Never & 185 & .082 & 108 & -.03 & .40 \\
\hline & 2. Sometimes & .004 & 091 & 1.000 & -.23 & .24 \\
\hline & 4. Always & -.040 & .092 & .973 & -.28 & .20 \\
\hline & 1. Never & $.225^{*}$ & .081 & .029 & .02 & .43 \\
\hline \multirow[t]{2}{*}{ 4. Always } & 2. Sometimes & .044 & .091 & .963 & -.19 & .28 \\
\hline & 3. Frequently & .040 & .092 & .973 & -.20 & .28 \\
\hline
\end{tabular}

* The mean difference is significant at the level of 0.05 .

Source: authors' calculation

Despite the statistical significance, the actual difference between the mean values of the groups is of small significance. The size of this difference expressed using squared association degree indicator (i.e. Eta square) is 0.035 for $F(3.293)=3.5$. This means that in relation to the size of the effect, $3.5 \%$ of the variability in the measurements of the dependent variable can be explained by belonging to a group.

Based on this analysed results of the variable c.2, it can be concluded that supervision over the compliance of financial statements with the regulatory framework by internal bodies contributes to the evaluation of comparability of financial statements at the level of Serbia. Therefore, the above results indicate that the null hypothesis $\mathrm{HO}$ is confirmed, in part of auxiliary 
Milutinović S., Medved I.: Supervision of Financial Reporting Through the Prism of...

hypothesis H02: supervision over the compliance of financial statements with the regulatory framework by internal bodies contributes to the comparability of financial statements at the level of Serbia.

\subsection{Degree of Correlation Between Supervision and Comparability of Financial Statements in Domestic Practice}

Using Pearson's correlation coefficient, Spearman's and Kendall's rank correlation coefficient, correlation was studied between $c .1$ - in the last three years, the internal authorities exercised supervision over the process of preparation and presentation of financial statements, and the comparability of financial statements at the level of Serbia, and c.2 - in the last three years, the internal authorities exercised supervision over compliance of financial statements with the regulatory framework and the comparability of financial statements at the level of Serbia.

Table 6: Parametric correlation for independent variables c. 1 and c.2

\begin{tabular}{|c|c|c|c|}
\hline & & $\begin{array}{l}\text { Supervision over the } \\
\text { preparation and } \\
\text { presentation of FS by } \\
\text { internal bodies } \\
\end{array}$ & $\begin{array}{c}\text { Supervision over } \\
\text { compliance of FS with } \\
\text { regulatory framework by } \\
\text { internal bodies }\end{array}$ \\
\hline \multirow{3}{*}{$\begin{array}{l}\text { Comparability of } \\
\text { FS with FS of } \\
\text { legal entities in } \\
\text { Serbia }\end{array}$} & $\begin{array}{l}\text { Pearson } \\
\text { Correlation }\end{array}$ & $.139^{*}$ & $.168^{* *}$ \\
\hline & Sig. (2-tailed) & .016 & .004 \\
\hline & $N$ & 297 & 297 \\
\hline
\end{tabular}

Source: authors' calculation

With probability of $95 \%$ a positive weak correlation is determined between two variables $r=0.139$ (see Table 6); tau_b $=0.121$; $r$ ho $=0.133$ (see Table 7) with $\mathrm{N}=297$ at the level of $\mathrm{p}<0.05$, which means that a high level of internal supervision over the process of preparation and presentation of financial statements is accompanied by a high level of comparability of financial statements at the level of Serbia.

With probability of $99 \%$ a positive weak correlation is determined between two variables $r=0.168$ (see Table 6); tau_b $=0.158$; $r h o=0.174$ (see Table 7) with $\mathrm{N}=297$ at the level of $\mathrm{p}<0.01$, which means that a high level of internal supervision over compliance of financial statements with the regulatory framework is accompanied by a high level of comparability of financial statements at the level of Serbia. 
Milutinović S., Medved I.: Supervision of Financial Reporting Through the Prism of...

Based on Pearson's correlation coefficient (see Table 6), the coefficient of determination $r^{2}=0.019$ is calculated; 0.028 which indicates that the implemented internal supervision over the process of preparation and presentation of financial statements accounts for $1.9 \%$ of the variance in respondents' answers on the comparability of financial statements at the level of Serbia, as well as that carried out internal supervision over compliance of financial statements with a regulatory framework explains $2.8 \%$ of the variance in respondents' answers on the comparability of financial statements at the level of Serbia.

Table 7: Nonparametric correlation for independent variables c.1 and c.2

\begin{tabular}{|c|c|c|c|c|}
\hline & & & $\begin{array}{l}\text { Supervision over the } \\
\text { preparation of FS by } \\
\text { internal bodies }\end{array}$ & $\begin{array}{c}\text { Supervision over } \\
\text { compliance of FS } \\
\text { with regulatory } \\
\text { framework }\end{array}$ \\
\hline \multirow{3}{*}{$\begin{array}{l}\text { Kendall's } \\
\text { tau_b }\end{array}$} & \multirow{3}{*}{$\begin{array}{l}\text { Comparability } \\
\text { of FS with FS } \\
\text { of legal } \\
\text { entities in } \\
\text { Serbia }\end{array}$} & $\begin{array}{l}\text { Correlation } \\
\text { Coefficient }\end{array}$ & $.121^{*}$ & $.158^{* *}$ \\
\hline & & Sig. (2-tailed) & .021 & .003 \\
\hline & & $N$ & 297 & 297 \\
\hline \multirow{3}{*}{$\begin{array}{l}\text { Spearman's } \\
\text { rho }\end{array}$} & $\begin{array}{l}\text { Comparability } \\
\text { of FS with FS }\end{array}$ & $\begin{array}{l}\text { Correlation } \\
\text { Coefficient }\end{array}$ & $.133^{*}$ & $.174^{* *}$ \\
\hline & of legal & Sig. (2-tailed) & .021 & .003 \\
\hline & $\begin{array}{l}\text { entues In } \\
\text { Serbia }\end{array}$ & $N$ & 297 & 297 \\
\hline
\end{tabular}

Source: authors' calculation

Based on the analysed results of the variable c.1, it can be concluded that there is a positive weak correlation between the supervision conducted by the internal bodies over the process of preparation and presentation of financial statements, and the comparability of financial statements at the level of Serbia. The same results indicate that the null hypothesis $\mathrm{HO}$ is confirmed, in part of the auxiliary hypothesis H03: There is a statistical and positive correlation between the supervision over the process of preparation and presentation of financial statements by internal authorities and comparability of financial statements at the level of Serbia.

Based on the analysed results of the variable c.2, it can be concluded that there is a positive weak correlation between the supervision conducted by the internal bodies over the compliance of financial statements with the regulatory framework and the comparability of financial statements at the level of Serbia. The same results indicate that the null hypothesis $\mathrm{HO}$ is confirmed, in part of the auxiliary hypothesis H04: There is a statistically significant and positive correlation between the supervision over compliance of financial statements 
Milutinović S., Medved I.: Supervision of Financial Reporting Through the Prism of...

with a regulatory framework by the internal authorities and the comparability of financial statements at the level of Serbia.

\section{Conclusions}

Comparison between the legal and current international regulation proved the existence of a (partial) non-compliance of domicile regulations with the EU regulations. Although Directive 2013/34/EU is not binding, and the EU recommends to incorporate its wording in the national legislation, it is noted that domestic regulations do not comply with the Directive in the following sections: scope, responsibility and obligation of developing and publishing financial statements, obligation of drafting the consolidated financial statements, classification thresholds for groups of legal entities, the elements of financial reporting in part of additional financial statements, regular financial reporting structure, compulsory audit of financial statements, preparation of management reports, preparation of half-yearly reports for listed companies, electronic publication of financial statements, or in part of the approval and registration of audit companies.

Based on the research results, the null hypothesis is accepted and it was proved that supervision in financial reporting contributes to the comparability of financial statements in terms of consistent application of the regulatory framework. This outcome resulted in conclusions that follow.

The state should actively engage, create the proper regulatory framework and develop the instruments of supervision over the process of financial reporting. The Sarbanes-Oxley Act is an excellent example of a successful state regulation of financial reporting. In the case of Serbia, state supervision in this area is desirable but it must be very carefully developed in order to avoid overlapping of jurisdictions of state authorities and the national professional organization, and clearly delimit their activities on the development of the financial reporting system. In addition, national authorities should be prepared to lose some of their absolute legislative sovereignty by letting international professional organizations make accounting regulations.

Raising the level of transparency of financial reporting and comparability of financial statements, preserving the credibility of the financial statements and the quality of accounting information can be achieved by adopting, implementing within the legal framework and consistent practical application of professional regulation. Therefore, the first step of the state meant would imply redefining and updating the legislation in terms of its convergence to the process of harmonization of financial reporting and good practices of European countries. Furthermore, it is necessary to start from the enactment of new legislation in this field, which would be fully compliant with applicable 
Milutinović S., Medved I.: Supervision of Financial Reporting Through the Prism of...

professional regulations and current world trends in this area, and taking into account the national, economic, political and cultural specificity of Serbia. Drafting a new law would be an easy task. A more challenging task would be to use the new legislation and build a reliable and effective system of supervision over financial reporting, which will provide high-quality financial statements comparable at the national and international level.

During the presentation of conclusions based on the research results, it is necessary to point attention on certain limitation in the study. Research results are not contrasted to research results of other authors in Serbia, because the same or similar research has not been conducted so far in domestic practice. Furthermore, foreign authors investigated the relation between the internal control over financial reporting and different dependent variables, but have not investigated the relation between the internal supervision in financial reporting and comparability of financial statements prepared on the basis of the regulatory framework. So research results could not be clearly contrasted to research results of foreign authors.

\section{References}

Abbott, L. J., Daugherty, B., Parker, S., \& Peters, G. F. (2016). Internal audit quality and financial reporting quality: The joint importance of independence and competence. Journal of Accounting Research 54(1), 3-40. doi: 10.1111/1475679X.12099

Altamuro, J., \& Beatty, A. (2010). How does internal control regulation affect financial reporting? Journal of Accounting and Economics 49(2010), 58-74. doi:10.1016/j.jacceco.2009.07.002

Azzali, S., \& Mazza, T. (2013). Internal control over financial reporting quality and information technology control frameworks. In D. Mancini, E. H. J. Vaassen \& R. P. Dameri (Eds.), Accounting information systems for decision making (pp. 4762). Berlin, Germany: Springer International Publishing AG.

Bardhan, I., Lin, Sh., \& Wu, Sh. L. (2015). The quality of internal control over financial reporting in family firms. Accounting Horizons 29(1), 41-60. doi: http://dx.doi.org/10.2308/acch-50935

Bentley-Goode, K. A., Newton, N. J., \& Thompson, A. (2015). Business strategy and internal control over financial reporting. Retrieved from: http://ssrn.com/abstract=2637688 or http://dx.doi.org/10.2139/ssrn.2637688

Dobija, D. (2015). Exploring audit committee practices: Oversight of financial reporting and external auditors in Poland. Journal of Management \& Governance 19(1), 113-143. doi: 10.1007/s10997-013-9281-6

Doyle, J., Ge, W., \& McVay, S. (2007). Determinants of weaknesses in internal control over financial reporting. Journal of Accounting and Economics 44(2007), 193223. doi:10.1016/j.jacceco.2006.10.003 
Milutinović S., Medved I.: Supervision of Financial Reporting Through the Prism of...

Feng, M., Li, Ch., McVay, S., \& Skaife, H. (2015). Does ineffective internal control over financial reporting affect a firm's operations? Evidence from firms' inventory management. The Accounting Review 90(2), 529-557. doi: 10.2308/accr-50909

Ge, W., Li, Z., Liu, Q., \& McVay, S. (2016). When does internal control over financial reporting curb resource extraction? Evidence from China. Retrieved from: http://ssrn.com/abstract=2704663 or http://dx.doi.org/10.2139/ssrn.2704663

IASB. (2010). Conceptual Framework for Financial Reporting. London: Author.

Isaac, A. (1951). Revision und wirtschaftsprüfung. Wiesbaden: Gabler Verlag.

Klikovac, A. (2009). Financijsko izveštavanje u Europskoj uniji. Zagreb: Mate.

Marinovic, I. (2013). Internal control system, earnings quality and the dynamics of financial reporting. The RAND Journal of Economics 44(1), 145-167. doi: 10.1111/1756-2171.12015

Miletić, D. (2014). Cash flow statement: Assessment of situation and application problems in Serbia. Industrija, 42(4), 99-114.

Ministarstvo finansija RS. (2014). Informator o radu Ministarstva finansija. Belgrade: Author. Retrieved from http://www.mfin.gov.rs

Mitrović, S. (2013). Institucionalni regulatorni okvir kao uslov kvaliteta finansijskog izveštavanja u Srbiji. Zbornik radova 44. simpozijuma Računovodstveno regulatorno okruženje: podsticaj ili ograničenje privrednog rasta. Belgrade: Association of Accountants and Auditors of Serbia.

Official Gazette of RS. (2013). Accounting Law (62/2013). Belgrade: Author.

Official Gazette of RS. (2016). Law on Tax Procedure and Tax Administration (80/2002, ... 15/2016). Belgrade: Author.

Stojanović, R., \& Petrović, P. (2013). Novi zakon o računovodstvu (opšte napomene). Računovodstvena praksa, 16-17/13.

Šabović, Š. (2011). Primena Međunarodnih računovodstvenih standarda u zemljama u razvoju u uslovima krize. Ekonomika, 2. 
